Historic, Archive Document

Do not assume content reflects current scientific knowledge, policies, or practices. 



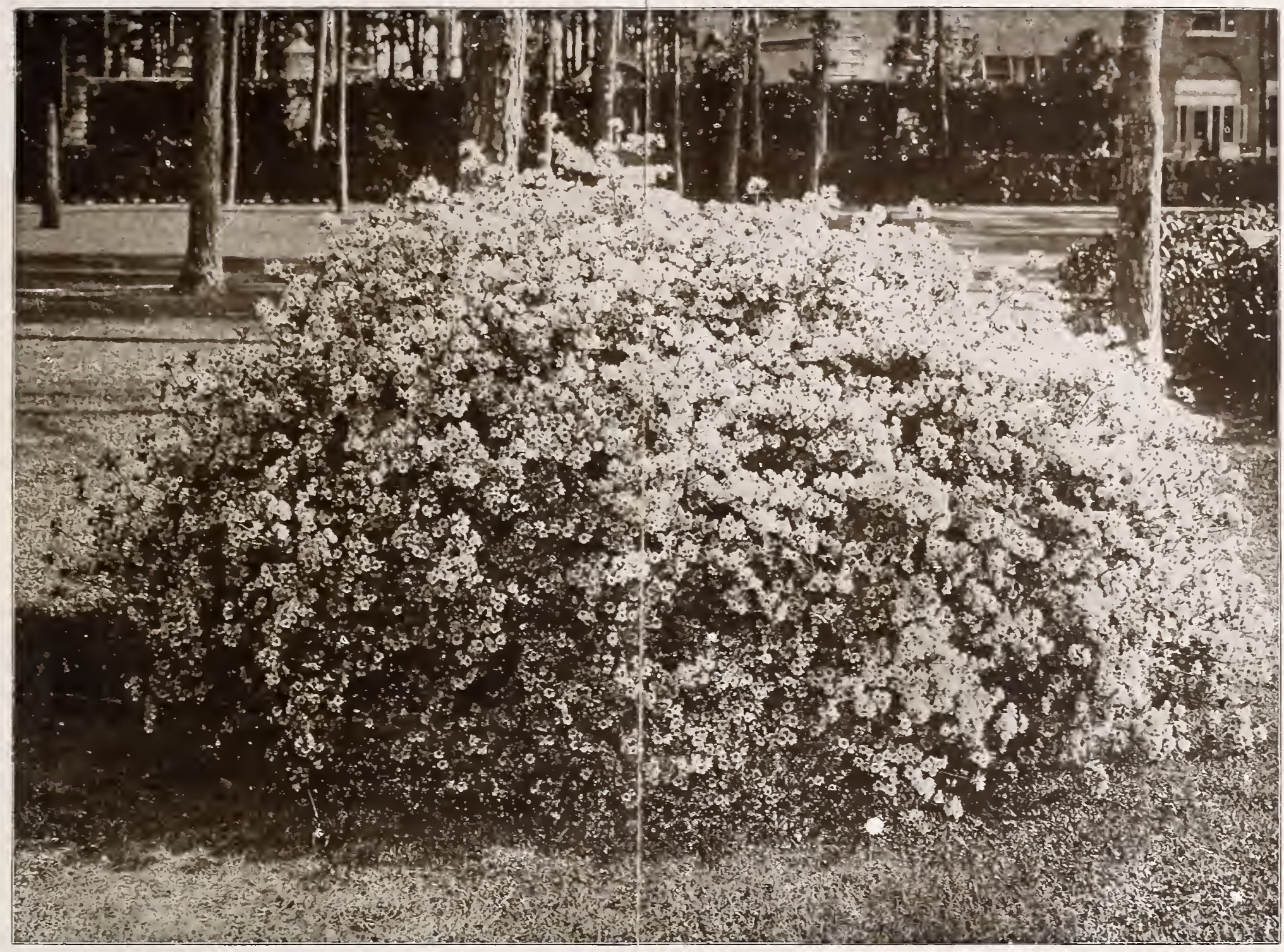

Look at this large specimen plant of Azalea amoena and try to picture in your mind the glorious effect those

\section{THE CHOICEST HARDY AZALEA}

OHADE-LOVING plants are scarce, very scarce; you know that if you have ever tried to plant $\mathrm{S}$ Among the few plants suitable for such a place, the beautiful carmine-flotvered Azalea
amoena is well adapted, doing also very well in an open position.

flowers. It is such a persistent flowering plant that the small cuttings from which we grow our stocky plants, frequently bloom.

In our experience with this grand evergreen Azalea, we have yet to find a nurseryman who has had more, if as great success in growing strong, stocky plants as we have them. There is a knack in raising the plants and getting them healthy and vigorous.

Our stock at this writing is a sight to see. Each plant is bushy and well formed, and though none approach this specimen in size, all are full of buds that predict a big display of bloom.

Here are some suggestions you will find helpful, no doubt.

\section{SHADY PLACES :}

In front of your porch, near old trees where the shade prevents other shrubs from growing, or in some shady nook or corner, you can get a bright and cheerful effect with a cluster of these beautiful Azaleas. In placing them in such a position, you need to see that good soil is supplied to give them a start. PLANTED IN BEDS:

A bed of these dwarf, bushy-growing Azaleas is a rare sight, and one to be prized by any lover of plants and flowers. All through the winter they are still pretty with their bronze- and green-colored foliage.

In planting a bed of these plants, estimate on setting the plants 18 to 20 inches apart.

\section{AS SPECIMENS:}

The above illustration speaks for itself. Of course, it takes some time for a plant to get this size, but such a sight as this one gives is well worth the waiting.

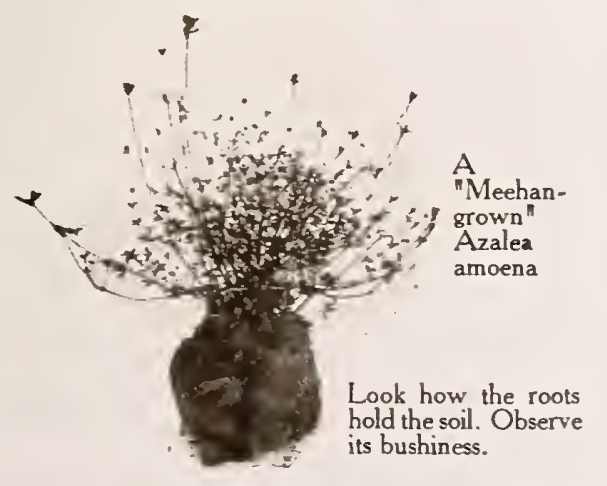

9 to 12 inches; pot-grown; bushy; 50 to 75 buds to one plant; 75 cents each; 10 for $\$ 5.00 ; 25$ for $\$ 10.00$ 12 to 18 inches; bushy, well-formed, field-grown plants; 75 to 150 buds : $\$ 1.00$ each; 10 for $\$ 6.00,25$ tor $\$ 12.50$ 75 to 125 buds to one plant;
$\$ 1.00$ each; 10 for $\$ 7.50 ; \mathbf{2 5}$ for $\$ 15.00$

THOMAS MEEHAN \& SONS, Inc. GROWERS OF THE RIGHT KIND OF HARDY PLANTS GERMANTOWN, PHILADELPHIA, PA. 
SPECIAI. - These Azaleas

have just finished flower-

ing. Get plants at once

and prepare for a grand

display next spring. They

will move nicely now.

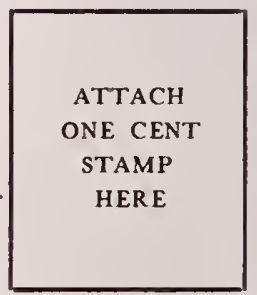

